\title{
Emergence date effects on resource partitioning between diffuse knapweed seedlings
}

\author{
ROGER L. SHELEY AND LARRY L. LARSON
}

\begin{abstract}
Authors are assistant professor Department of Plant, Soil and Environmental Sciences, Montana State University, Bozeman, Mont. 59717 and associate professor Department of Rangeland Resources, Oregon State University, Corvallis, Ore. and is stationed at OSU-EOSC Agriculture Program, Eastern Oregon State College, La Grande, Ore. 97850.
\end{abstract}

\begin{abstract}
Diffuse knapweed (Centaurea diffusa Lam.) has reduced forage production, watershed quality, and biodiversity, and increased soil erosion on millions of hectares of rangeland. Diffuse knapweed has evolved mechanisms that allow it to dominate sites in nearly monotypic stands. Understanding these mechanisms may provide useful information in developing weed management strategies. Objectives of this study were to investigate interference, growth rates, and resource partitioning between early and late emerging diffuse knapweed seedlings. Seeds of diffuse knapweed were planted 21 March (early emerging) and 14 April (late emerging) 1993 in addition series mixtures with total stand densities ranging from 1,000-7,000 plants $\mathrm{m}^{-2}$. Shoots were harvested on 1 and 2 June 1993. The greatest interference was among coemerging seedlings. Resource partitioning ratios (51 and 1398) indicated substantial partitioning between seedlings having different emergence dates. Continuous seedling emergence may allow diffuse knapweed to occupy all available safe sites.
\end{abstract}

Key Words: Centaurea diffusa, continuous seedling recruitment, interference, niche occupancy.

Diffuse knapweed (Centaurea diffusa Lam.) was introduced into North America and Canada from Eurasia around the turn of the century (Roché and Roché 1988). Since its introduction, diffuse knapweed has invaded millions of hectares of rangeland in the northwestern United States and adjoining Canadian provinces (Roché and Roché 1988, Watson and Renney 1974). In general, members of the genus Centaurea (knapweeds) form near monocultures, reducing biodiversity, wildlife and livestock forage production, and are detrimental to soil and water resources (Lacey et al. 1989, Maddox 1979, Myers and Berube 1983, Tyser and Key 1988, Watson and Renney 1974).

Dense diffuse knapweed stands are believed to result from differential grazing resistance and altered competitive interactions between the knapweeds and preferred grasses (Briske 1990, Powell 1990). However, excellent condition rangelands are being invaded by knapweeds in the absence of livestock grazing (Schuller 1992, Tyser and Key 1988).

Published as Montana State University Agri. Exp. Tech. Paper No. J-4031.

Manuscript accepted 14 Sept. 1995.
Individual knapweed plants possess many traits that are advantageous over perennial grasses in site occupation. Intense competitiveness, rapid growth rates, large seed output, and extended growing periods all contribute to the successful domination of grasslands by knapweeds (Sheley et al. 1993, Sheley and Larson 1994a, Sheley and Larson 1994b).

Population characteristics also may provide insight into the monotypic domination of grasslands by diffuse knapweed. Seed development and release by diffuse knapweed allows continuous seed rain upon the soil surface (unpublished data, R.L. Sheley and L.L. Larson). Moreover, diffuse knapweed exhibits germination polymorphism which distributes seed germination over time (Nolan and Upadhyaya 1988). Life history models of diffuse knapweed suggest that a conspecific hierarchy of plant size classes result from continuous seedling emergence (unpublished data, R.L. Sheley and L.L. Larson). Continuous weed seedling recruitment into a population may be an important mechanism providing intraspecific temporal resource partitioning and safe site occupation.

Understanding the mechanisms which allow weeds to dominate rangeland provides the basis for identifying plant traits and population strategies of desirable species that may minimize weed invasion (Larson et al. 1994). Knowledge of these mechanisms may allow development of more effective and efficient management strategies. The objectives of this study were to compare the growth rate of seedlings of diffuse knapweed having 2 emergence dates, and to investigate interference and resource partitioning between early and late emerging diffuse knapweed seedlings.

\section{Materials and Methods}

\section{Study Sites}

Field studies were conducted during 1993 in southeastern Washington (site 1: $45^{\circ} 57^{\prime} \mathrm{N}, 119^{\circ} 22^{\prime} \mathrm{W}$; site 2: $46^{\circ} 2^{\prime} \mathrm{N}, 119^{\circ}$ $26^{\prime} \mathrm{W}$ ) to evaluate the effect of emergence date on resource partitioning between diffuse knapweed seedlings. Study site 1 lies within the bluebunch wheatgrass (Pseudoroegneria spicata (Pursh.) Löve)-needle and thread grass (Stipa comata Trin. \& Rupr.) habitat type. The soil, a Warden very fine sandy loam (coarse, silty, mixed, mesic, Xerollic Camborthids) has a 15 to $30 \%$ southerly slope and an elevation of $450 \mathrm{~m}$. Study site 2 is located within the bluebunch wheatgrass-Sandberg bluegrass (Poa sandbergii Vasey) habitat type (Daubenmire 1970). The soil 
at this study site was a Ritzville silt loam (coarse, silty, mixed, mesic, Calciothiodic Haploxerol), with zero slope and an elevation of $1,150 \mathrm{~m}$. Average annual precipitation for study site 1 ranges from 155 to $228 \mathrm{~mm}$ and 228 to $305 \mathrm{~mm}$ for study site 2 .

Both sites were dominated by diffuse knapweed at the time of the study. Seeds used to establish diffuse knapweed seedlings during the study were collected from the study sites during the summer of 1992.

Temperature (maximum and minimum), precipitation (24 hour), and soil water potential (MPa) were monitored daily at each site using the Washington Public Agriculture Weather System (Wright and Ley 1990). Data were summarized (means or totals) on 12-day intervals to correspond with experimental harvest dates (Table 1)

Table 1. Environmental conditions at study sites. ${ }^{1}$

\begin{tabular}{|c|c|c|c|c|c|}
\hline \multirow[t]{2}{*}{ Site } & \multirow[t]{2}{*}{ Period (1993) } & \multirow{2}{*}{$\begin{array}{c}\text { Total } \\
\text { precipitation }\end{array}$} & \multirow{2}{*}{$\begin{array}{c}\text { Mean soil } \\
\text { water } \\
\text { potential }^{2}\end{array}$} & \multicolumn{2}{|c|}{ Mean temperature } \\
\hline & & & & $\max$. & $\min$. \\
\hline & & $(\mathrm{mm})$ & $(\mathrm{MPa})$ & $\ldots \ldots$ & $-\ldots$ \\
\hline \multirow[t]{6}{*}{1} & $21 \mathrm{March}$ - 2 April & 5 & -0.04 & 15.6 & 5.3 \\
\hline & 3 April - 14 April & 5 & -0.04 & 18.1 & 4.4 \\
\hline & 15 April - 26 April & 4 & -0.08 & 18.6 & 4.4 \\
\hline & 27 April - 8 May & 8 & -0.36 & 15.0 & 4.4 \\
\hline & 9 May - 20 May & 2 & -0.90 & 30.6 & 12.5 \\
\hline & 21 May - 1 June & 11 & -292.80 & 25.1 & 10.8 \\
\hline \multirow[t]{6}{*}{2} & 21 March - 2 April & 15 & -0.03 & 16.8 & 5.3 \\
\hline & 3 April - 14 April & 6 & -0.03 & 14.3 & 5.3 \\
\hline & 15 April - 26 April & 11 & -0.03 & 17.7 & 3.9 \\
\hline & 27 April - 8 May & 9 & -0.03 & 17.1 & 9.1 \\
\hline & 9 May - 20 May & 4 & -0.04 & 29.7 & 12.1 \\
\hline & 21 May - 1 June & 12 & -0.19 & 23.7 & 10.4 \\
\hline
\end{tabular}

Environmental conditions were monitored daily. Twelve day values are presented during the study to correspond with harvest dates.

${ }^{2}$ Soil water potential measured at $20 \mathrm{~cm}$.

\section{Growth of Isolated Plants}

Isolated plants were established by broadcast seeding 50 diffuse knapweed seeds into $0.25 \mathrm{~m}^{2}$ plots. The seeds were hand separated to provide a uniform distribution, and lightly covered $(<2 \mathrm{~mm})$ with soil. Each plot was watered at the rate of 1 liter $\mathrm{m}^{2}$ at the time of planting to synchronize germination and then thinned to a single individual 7 days after emergence. Plots were established on either 21 March (early emerging treatment) or 14 April (late emerging treatment) 1993. Treatments (plots) were replicated to provide 5 harvest dates and 5 blocks in a randomized-block-design ( 2 emergence dates, 5 harvest dates, 5 blocks). The experiment was conducted at each site. Harvest dates occurred on 12-day intervals beginning 24 days after planting. Final harvest occurred on 1 June (site 1) and 2 June (site 2) 1993. Shoots were dried at $60^{\circ} \mathrm{C}$ for 48 hours and weighed. Data were analyzed as a split-plot using analysis of variance with site as the wholeplots and isolated individuals as subplots. Shoot weight comparisons between isolated early and late emerging seedlings were made using data from 24,36 , and 48 days after planting.

\section{Interference and Resource Partitioning}

Mixtures of early and late emerging diffuse knapweed seedlings were grown to assess interference and resource parti- tioning between seedlings having 2 emergence dates. Mixtures of diffuse knapweed seeds were planted 21 March (early emerging) and 14 April (late emerging), 1993 in $0.5 \mathrm{~m}^{2}$ plots using the same procedures described for the growth rate study. The majority of seeds planted on 21 March emerged on 14 April and the majority of the seeds planted on 14 April emerged 8 May 1993. Diffuse knapweed seedlings were then thinned 7 days after emergence to provide an addition series (Spitters 1983). Early to late emerging seedling densities were 500:500, 500:1500, 500:2500, $500: 3500,1500: 500,1500: 1500,1500: 2500,1500: 3500$, $2500: 500,2500: 1500,2500: 2500,2500: 3500,3500: 500$, $3500: 1500,3500: 2500,3500: 3500$ plants $\mathrm{m}^{-2}$. Early emerging seedlings were labeled on 16 and 17 April using a plastic color coded wire placed around their base. Density treatments were replicated 5 times to form a randomized-complete-block design (16 density combinations, 5 blocks) at each study site. Ten randomly selected early and late emerging plants from the interior of each plot were harvested on 1 (site 1) and 2 (site 2) June 1993. Harvested biomass was dried at $60^{\circ} \mathrm{C}$ for 48 -hours and weighed. Rosettes harvested from plots with high and low densities had 3-4 and 7-8 leaves, respectively.

Addition series data were incorporated into multiple linear models using SPSSPC+ least squares regression procedures (SPSS., Chicago, Illinois) of the form:

$$
\begin{aligned}
& W_{e}=\beta_{e o}+\beta_{e e} N_{e}+\beta_{e l} N_{l} \\
& W_{1}=\beta_{l o}+\beta_{11} N_{1}+\beta_{l e} N_{e}
\end{aligned}
$$

where $W_{e}$ and $W_{1}$ were the average per-plant shoot weights for early and late emerging knapweed, respectively, and $N_{e}$ and $N_{l}$ were their respective densities. Scatterplots of the residual vs. standardized predicted values were used to determine the homogeneity of variances and degree of model fit. T-tests $(P<0.05)$ were used to determine significance of the regression coefficients.

The regression coefficients $\beta_{\mathrm{eo}}$ and $\beta_{\mathrm{lo}}$ estimate maximum shoot weight of an isolated early or late emerging knapweed seedling, respectively. Regression coefficients $\beta_{\mathrm{ee}}$ and $\beta_{\mathrm{ll}}$ estimate intraspecific interference among co-emerging seedlings. Interference between early and late emerging seedlings is estimated by the $\beta_{\mathrm{el}}$ and $\beta_{\mathrm{le}}$ regression coefficients. Coefficient of determination $\left(R^{2}\right)$ values were calculated to indicate the proportion of the variation found in shoot weight $\left(\mathrm{W}_{\mathrm{e}}\right.$ or $\left.\mathrm{W}_{\mathrm{l}}\right)$ that was accounted for using plant density $\left(\mathrm{N}_{e}\right.$ and $\left.\mathrm{N}_{1}\right)$.

Coefficient ratios, $\beta_{\mathrm{ee}}: \beta_{\mathrm{el}}$ and $\beta_{\mathrm{ll}}: \beta_{\text {le }}$, were used to determine the relative influence of seedling emergence date on shoot weight. Zero was used for non-significant coefficients in regression models, and a constant of 0.0001 was used in ratio calculations (Roush 1988). The $\left[\beta_{\mathrm{ee}}: \beta_{\mathrm{el}} / \beta_{\text {le }}: \beta_{1]}\right]$ double ratio was used to assess partitioning (niche separation) of resources between early and late emerging diffuse knapweed seedlings (Connolly 1986). Deviations from unity indicate increased resource partitioning.

\section{Results and Discussion}

\section{Growth of Isolated Individuals}

Analysis of variance showed that the accumulation of shoot weight was similar between early and late emerging knapweed seedlings at 24,36, and 48 days after planting and between sites. Differences in the accumulation of shoot weight at any specific harvest, therefore, were due to the duration of growth rather than 
environmental effects for isolated individuals. Combined shoot weight increased with increasing harvest dates $(\mathrm{P}<0.0001)$, and were $1.5 \pm 0.4,4.1 \pm 1.7$, and $14.6 \pm 4.7 \mathrm{mg}$ for 24,36 , and 48 days after planting, respectively. Mean shoot weight of the early emerging isolated knapweed seedlings was $141 \pm 14.2 \mathrm{mg} 72$ days after planting.

\section{Interference and Resource Partitioning}

Analysis of variance of regression coefficients calculated from addition series data for each replication indicated the results were not significantly different between sites. However, data were not combined because of poor model fitness for the late emerging seedlings at site 2 .

The regression models indicated that co-emerging knapweed seedlings influenced their own shoot weight more than did seedlings emerging either later or earlier (Tables 2 and 3). On site

Table 2. Multiple regression analysis ${ }^{1}$ for the prediction of shoot dry weight $(\mathrm{mg})$ of early emerging diffuse knapweed seedlings ${ }^{2}$.

\begin{tabular}{lccccc}
\hline \hline Site & $\beta_{\mathrm{eo}}$ & $\beta_{\mathrm{ee}}$ & $\beta_{\mathrm{el}}$ & $\beta_{\mathrm{ee}} / \beta_{\mathrm{el}}$ & $\mathrm{R}^{2}$ \\
\hline 1 & 144.73 & -0.034 & 0.0 & 340 & $0.77[0.77]^{3}$ \\
& $(4.78)$ & $(0.002)$ & $(\mathrm{NS})$ & & \\
2 & 167.75 & -0.0420 & -0.0032 & 13 & $0.91[0.90]$ \\
& $(4.63)$ & $(0.0015)$ & $(0.0015)$ & & \\
\hline
\end{tabular}

${ }_{2}^{1} w_{e}=\beta_{e 0}+\beta_{e e} N_{e}+\beta_{e l} N_{1}$

${ }^{2}$ The intercept Beo estimated the shoot weight of an isolated early emerging knapweed seedling. Interference among early emerging seedlings is measured by the regression coefficient $\beta_{e e}$. The effects of interference between early and late emerging seedlings on early emerging seedlings is estimated by $\beta_{\mathrm{el}}$. Numbers in parentheses are standard errors for coefficients significantly different from zero.

Numbers in brackets are the coefficient of determination $\left(R^{2}\right)$ values indicating the proportion of variability associated with early emerging knapweed shoot weight that was accounted for by the density of early emerging seedlings.

1, early emerging seedling shoot weight was not influenced by the late emerging seedlings (Table 2). On site 2 , the early emerging seedlings had 13 times the effect of late emerging seedlings on the early emerging seedling shoot weight. The predicted shoot weight of isolated individuals emerging early was about 145 and $168 \mathrm{mg}$ for site 1 and site 2 , respectively. Each 1,000 plants $\mathrm{m}^{-2}$ increase in early emerging seedlings reduced their shoot weight by an average of $38 \mathrm{mg}$.

Later-emerging diffuse knapweed seedlings had about 4 times the influence on late-emerging seedling-shoot weight than did

Table 3. Multiple regression analysis ${ }^{1}$ for the prediction of shoot dry weight (mg) of late emerging diffuse knapweed seedlings ${ }^{2}$.

\begin{tabular}{llcccc}
\hline \hline Site & $\beta_{\text {lo }}$ & $\beta_{\text {ll }}$ & $\beta_{\text {le }}$ & $\beta_{\text {ll }} / \beta_{\text {le }}$ & $\mathrm{R}^{2}$ \\
\hline 1 & 16.4 & -0.0037 & -0.0009 & 4.11 & $0.80[0.76]^{3}$ \\
& $(0.625)$ & $(0.0002)$ & $(0.0002)$ & & \\
2 & 22.9 & -0.0052 & -0.0013 & 4.00 & $0.54[0.51]$ \\
& $(1.02)$ & $(0.0005)$ & $(0.0005)$ & & \\
\hline
\end{tabular}

${ }_{2}^{1} \mathrm{~W}_{1}=\beta_{10}+\beta_{11} \mathrm{~N}_{1}+\beta_{1 e^{N}} \mathrm{~N}_{e}$

The intercept $\beta_{10}$ estumated the shoot weight of an isolated late emerging knapweed seedling. Interference among late emerging seedlings is measured by the regression coefficient $\beta_{11}$. The effects of interference between early and late emerging seedlings on late emerging seedlings is estimated by $\beta_{\text {le }}$. Numbers in parentheses are standard errors for coefficients significantly different from zero.

${ }^{3}$ Numbers in brackets are the coefficient of determination $\left(\mathrm{R}^{2}\right)$ values indicating the proportion of variability associated with early emerging knapweed shoot weight that was accounted for by the density of early emerging seedlings. early-emerging seedlings (Table 3). The predicted shoot weight of isolated individuals emerging late was 16.4 and $22.9 \mathrm{mg}$. A 1,000 plant $\mathrm{m}^{-2}$ increase in late emerging seedlings reduced the predicted shoot weight of late emerging seedlings by $3.7 \mathrm{mg}$ for site 1 and $5.2 \mathrm{mg}$ for site 2 . The same increase in early-emerging seedlings reduced the predicted shoot weight of later-emerging knapweed seedlings by less than $1.3 \mathrm{mg}$.

The $\left[\beta_{\mathrm{ee}}: \beta_{\mathrm{el}} / \beta_{\mathrm{le}}: \beta_{11}\right]$ double ratio was 1398 and 51 based on shoot weight for site 1 and site 2 , respectively (Table 4 ). This indicates that strong resource partitioning occurs between late and early emerging knapweed seedlings which may be central to the ability of this species to dominate rangelands in near-monotypic stands.

Table 4. Double ratio $\left(\beta_{\mathrm{ee}}: \beta_{\mathrm{el}} / \beta_{\mathrm{ie}}: \beta_{\mathrm{II}}\right)$ assessing the resource partitioning between early and late emerging knapweed seedlings based on shoot weight. ${ }^{1}$

\begin{tabular}{cc}
\hline \hline Site & $\left(\beta_{\mathrm{ee}}: \beta_{\mathrm{el}} / \beta_{\mathrm{ie}} \beta_{\mathrm{ll}}\right)$ \\
\hline 1 & 1398 \\
2 & 51 \\
\hline
\end{tabular}

${ }^{1}$ Ratios other than unity indicate occurrence of resource partitioning.

It has been hypothesized that initial plant densities and timing of emergence have strong impacts on the dynamics of plant communities because they create asymmetries in plant size and resource capture (Grace 1990, Harper 1977, Ross and Harper 1972, Weiner 1990). Asymmetric competition (Weiner 1990) or resource preemption (Grace 1990) is thought to occur because of a positive feedback between growth and resource capture (Grime 1979, Harper 1977, Keddy 1990). In such a scenario, those individuals emerging and establishing earlier possess a one-sided competitive advantage (Firbank and Watkinson 1987). Our research suggests that competition between diffuse knapweed seedlings is 2-sided. Earlier emerging diffuse knapweed seedlings preempt resources and occupy safe sites proportional to their size, until all safe sites are captured, similar to that predicted by Ross and Harper (1972) and reported by Watts (1984). Early emerging seedlings do not encroach into areas already occupied by the smaller, later emerging plants, and further increase in size depends on vertical growth (Firbank and Watkinson 1987). In such a case, we speculate that the early emerging seedling roots extend deep enough into the soil that interference with late emerging seedling roots is minimized. Continuous seedling emergence allows diffuse knapweed to occupy all available safe sites with minimal interference from seedlings having different emergence dates. Species possessing mechanisms that allow continual seedling recruitment can capitalize on frequent but minimal periods of precipitation, characteristic of arid lands, by controlling and occupying safe sites as they become available.

Spatial pattern plays an important role in the mortality and flowering ability of diffuse knapweed. Mortality among seedlings and the number of non-flowering established plants increased with proximity to established plants (Powell 1990). Our study suggests that temporal pattern also may play a key role in the biology of diffuse knapweed. Using early and late emerging knapweed densities to predict shoot weight, the coefficient of determination $\left(R^{2}\right)$ was 0.77 and 0.80 (site 1 ) and 0.91 and 0.54 (site 2) for early and late emerging knapweed seedlings, respectively. Weldon and Slauson (1986) proposed that the $\mathrm{R}^{2}$ values 
generated from addition series regression models estimate the amount of the target plant's response to interference. In our study, all regression models indicate that interference plays an important role in shoot growth of co-emerging knapweed seedlings (Tables 2 and 3 ). We believe that spatial and temporal pattern interact to determine the outcome of interference and ultimately the success of diffuse knapweed individuals within the population.

In a plant community, various species continually vie to occupy safe sites that are compatible with their requirements for survival. Collectively, these species determine the structure and function of the plant community. Those species with the ability to capture safe sites and provide maximum community structure and function dominate (Larson et al. 1994). We speculate that diffuse knapweed, a semelparous perennial (Thompson and Stout 1991), has the ability to monotypically dominate rangelands, in part, because it continuously occupies safe sites and the hierarchy of size classes within the population maximizes plant community structure.

\section{Literature Cited}

Briske, D. D. 1990. Developmental morphology and physiology of grasses. p. 85-108 In: R. K. Heitschmitt and J. W. Stuth, eds. Grazing Management: An Ecological Perspective. Timber Press, Inc., Portland, Ore.

Connolly, J. 1986. On difficulties with replacement series methodology in mixture experiments. J. Appl. Ecol. 23: 125-127.

Daubenmire, R. 1970. Steppe vegetation of Washington. Washington Agric. Exp. Sta. Bull. No. 62.

Firbank, L. G. and Watkinson, A. R. 1987. On the analysis of competition of the level of the individual plant. Oecologia 71:308-317.

Grace, J. B. 1990. On the relationship between plant traits and competitive ability. p. 51-116 In: J. Grace and D. Tilman, eds. Perspectives on Plant Competition. Academic Press, New York, N.Y.

Grime, J. P. 1979. Plant Strategies and Vegetation Process. John Wiley and Sons, New York, N.Y. 222p.

Harper, J. L. 1977. Population Biology of Plants. Academic Press, London. 892p.

Keddy, P. 1990. Competitive hierarchies and centrifugal organization in plant communities. p. 265-290, In: J. Grace and D. Tilman, eds. Perspectives on Plant Competition. Academic Press, New York, N.Y.

Lacey, J. R., C. B. Marlow, and J. R. Lane. 1989. Influence of spotted knapweed (Centaurea maculosa) on surface runoff and sediment yield. Weed Technol. 3:627-631.

Larson, L. L., R. L. Sheley, and M. M. McInnis. 1994. Vegetation management and weed invasion. Sustainable Rangeland Symp. Oregon State Univ., LaGrande, Ore. (in press).

Maddox, D. M. 1979. The knapweeds: their economics and biological control in the western states, U.S.A. Rangelands. 1:139-143.

Myers, J. H. and D. Berube. 1983. Diffuse knapweed invasion into rangeland in the dry interior of British Columbia. Can. J. Plant Sci. 63:981-987.

Nolan, D. G. and M. K. Upadhyaya. 1988. Primary seed dormancy in diffuse and spotted knapweed. Can. J. Plant Sci. 68:775-783.

Powell, R. D. 1990. The role of spatial pattern in the population biology of Centaurea diffusa. J. Ecol. 78: 374-388.

Roché, C. T. and B. F. Roché, Jr. 1988. Distribution and amount of four knapweed (Centaurea L.) species in eastern Washington. Northwest Sci. 62:242-253.

Ross, M. A. and J. L. Harper. 1972. Occupation of biological space during seedling establishment. J. Ecol. 60:77-88.

Roush, M. L. 1988. Models of a four-species annual weed community: growth, competition, and community dynamics. Ph.D. Thesis. Oregon State Univ., Corvallis, Ore. 218p.

Schuller, R. 1992. Knapweeds invade natural areas. Knapweed 6:4.
Sheley, R. L. and L. L. Larson. 1994a. Observation: Comparative livehistory of cheatgrass and yellow starthistle. J. Range Manage. 47:450-456.

Sheley, R. L. and L. L. Larson. 1994b. Comparative growth and interference between cheatgrass and yellow starthistle seedlings. J. Range Manage. 47:470-474.

Sheley, R. L., L. L. Larson, and D. E. Johnson. 1993. Germination and root dynamics of range weeds and forage species. Weed Technol. 7:234-237.

Spitters, C. J. T. 1983. An altemative approach to the analysis of mixed cropping experiments. I. Estimation of competition effects. Neth. J. Agr.. Sci. 31:1-11.

Thompson, D. J. and D. G. Stout. 1991. Duration of the juvenile period in diffuse knapweed (Centaurea diffusa) Can. J. Bot. 69:368-371.

Tyser, R. W. and C. H. Key. 1988. Spotted knapweed in natural area fescue grasslands: an ecological assessment. Northwest Sci. 62:151-160.

Watson, A. K. and A. J. Renney. 1974. The biology of Canadian Weeds 6. Centaurea diffusa and C. maculosa. Can. J. Plant Sci. 54:687-701.

Watts. G. D. 1984. Some effects of plants on their neighbours. Trans Norfolk Norwich Nat. Hist. Soc. 26:259-271.

Weiner, J. 1990. Asymmetric competition in plant populations. Trends Ecol. \& Evol. 5:360-364.

Weldon, C. W. and W. L. Slauson. 1986. The intensity of competition versus its importance: an overlooked distinction and some implications. Q. Rev. Biol. 61:23-44.

Wright, M.A. and T.W. Ley. 1990. Washington public agricultural weather system user manual. Coop. Ext. Wash. State Univ. EB1547. 